\title{
FERTILIZING EXPERIMENTS WITH ANHYDROUS AMMONIA AT KOTKANIEMI
}

\author{
Yrjö Pessi, Jorma Syvälahti, Auvo Leskelä and Mikko Ylänen \\ Rikkihappo Oy, Helsinki
}

Received May, 28, 1971

\begin{abstract}
On spring cereals and in fertilization in connection with the sowing of winter cereals the effectiveness of ammonia is comparable to that of calcium ammonium nitrate. In tests that were arranged at Rikkihappo Oy's experimental farm Kotkaniemi it was established that anhydrous ammonia given in connection with spring cereal fertilization and autumn cereal earthing is equal to CAN in effect. 16 tests were carried out during a period of five years using placement fertilization the soil being silty clay in most cases. Differences did not occur in the grain yield, the 1000-grain number hl-weight or in the protein content of the grain crop. Urea proved to be less effective than the two other fertilizers.
\end{abstract}

The usage of anhydrous ammonia as a straight nitrogen fertilizer had a good start in the USA in the 1950's. This method of using nitrogen in an anhydrous form has also been investigated in many European countries, namely France, England, and Denmark (Anon. 1968). Especially in Denmark the usage of ammonia has increased rapidly, and in 1967 68 about 95000 tons of anhydrous ammonia was used rapidly as a fertilizer (Anon. 1969), and the figure is still going up.

Anhydrous ammonia $\left(\mathrm{NH}_{3}\right)$ contains $82.2 \%$ nitrogen $(\mathrm{N})$. Ammonia is usually a gas but under sufficient pressure it is possible to keep it liquid. While the temperature varies from $0^{\circ}$ to $+30^{\circ} \mathrm{C}$ the necessary pressure varies within 3.4 to $10.9 \mathrm{~kg} / \mathrm{cm}^{2}$. Owing to this, the ammonia storage and transport equipment have to meet certain requirements. When the ammonia is discharged from the application equipment it immediately turns into gas and gets fixed into the soil.

The only application method for ammonia is injection. In its effectiveness as a fertilizer ammonia has proved to be equal to other nitrogen fertilizers (SALONEN 1967, Cooke 1968, Jansson 1966, van Burg 1969). The equipment necessary for storage and injection, however, requires more capital than is needed in the use of bagged goods. How profitable the usage of ammonia is greatly depends on the distance of transportation, the kind of soil on the farm, the climatic conditions and the size of the farm (BUCHNER 1966).

Ammonia is not a suitable fertilizer for grassland (van Burg 1966, van Burg et al. 1967). In connection with the injection the roots of the plants are damaged and earthing 
can seldom be carried out properly. Nor is ammonia suitable for winter cereals in spring because it may uproot the plants in connection with the injection (vAN BURG et al. 1967). Autumn injection is often too risky in Western Europe because of larger N-losses in mild and wet winters. Under certain conditions, however, autumn application might be successful (van Burg 1969).

In Finland anhydrous ammonia has been used only in experiments. Fertilizing experiments with ammonia have been carried out on the Kotkaniemi experimental farm at Vihti, the total number of experiments being sixteen during five years, 1966-70. The experiments have been made with spring and winter cereals. The experiments have been carried out with a Danish Marsk Stig apparatus which is easy to use and has a satisfactory injection accuracy. When the experiments were started the tank of the machine was replaced by gas bottles filled with ammonia in order to perform fertilization to a depth of $15 \mathrm{~cm}$ and make the ammonia fix perfectly into the soil. The working of the cultivator at the back of the machine is weak.

The precipitations and the mean temperatures of the test years $(1965-70)$ are given in Table 1.

Table 1. Climatic conditions at Vihti during the growing seasons 1965-70.

Precipitation per month in $\mathrm{mm}$.

\begin{tabular}{lrrrrrr} 
& V & VI & VII & VIII & IX & Total \\
1965 & 8.3 & 18.1 & 106.9 & 90.0 & 65.0 & 288.3 \\
1966 & 15.1 & 40.7 & 74.9 & 28.3 & 77.7 & 236.7 \\
1967 & 51.9 & 21.8 & 27.8 & 142.1 & 53.3 & 296.9 \\
1968 & 70.5 & 30.6 & 67.1 & 111.4 & 74.4 & 354.0 \\
1969 & 21.6 & 15.5 & 45.3 & 40.1 & 95.9 & 218.4 \\
1970 & 26.4 & 20.3 & 130.4 & 34.1 & 61.8 & 273.0 \\
\hline Mean value & 32.3 & 24.5 & 75.4 & 74.3 & 71.3 & 277.8
\end{tabular}

Mean temperature per month in ${ }^{\circ} \mathrm{C}$

\begin{tabular}{lrrrrrr} 
& V & VI & VII & VIII & IX & $\begin{array}{c}\text { Mean value } \\
(\text { V-IX) }\end{array}$ \\
1965 & 7.7 & 16.0 & 14.6 & 13.4 & 11.6 & 12.66 \\
1966 & 9.4 & 17.9 & 17.9 & 13.8 & 7.9 & 13.38 \\
1967 & 10.1 & 14.7 & 17.6 & 15.2 & 10.5 & 13.62 \\
1968 & 7.4 & 16.2 & 14.5 & 15.3 & 10.0 & 12.68 \\
1969 & 8.7 & 15.3 & 16.2 & 15.2 & 9.6 & 13.00 \\
1970 & 9.3 & 16.2 & 16.0 & 14.4 & 9.2 & 13.00 \\
\hline Mean value & 8.8 & 16.0 & 16.1 & 14.5 & 9.8 & 13.04
\end{tabular}




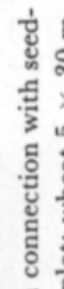
(1)

일

影

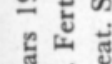

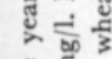

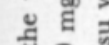

.

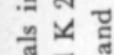

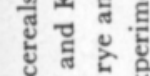

5

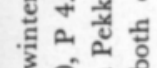

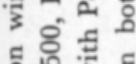

0
0

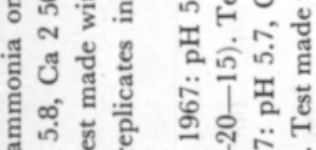

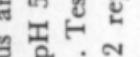

\%

年

更

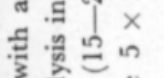

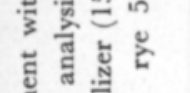

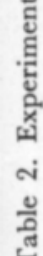

势

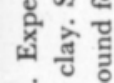

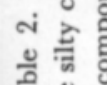

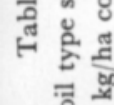

\%ํํำ

is

里

$s$

要要

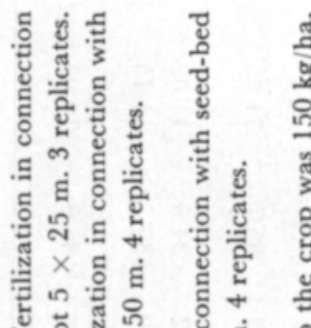

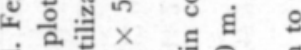

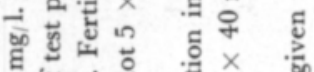

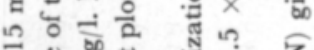

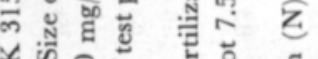

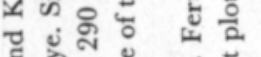

ल के के

을

我施

응 ․ㅡㄴ

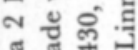

ช็ สำ

की

再

而要

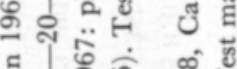

5 은 은

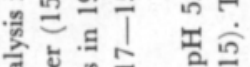

앨

랑 娄

㐫苛

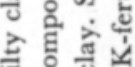

(5)

동

का

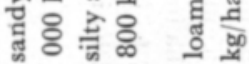

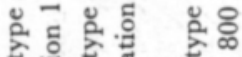

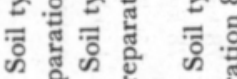

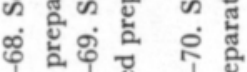

1 范

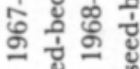

.

总焉

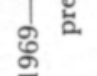

a

문

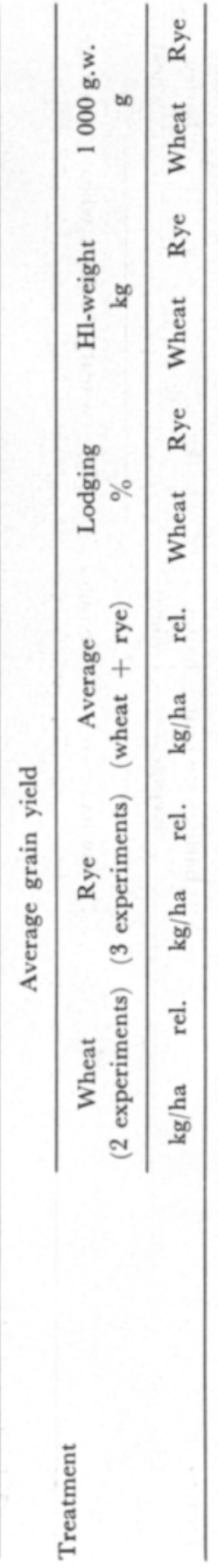

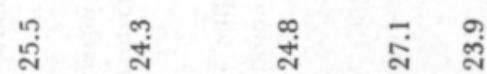

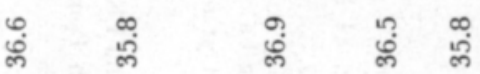

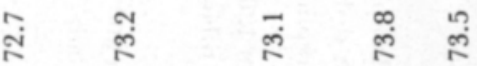

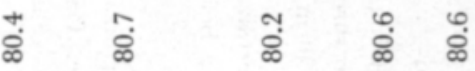

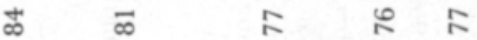

- 0 0 00

흐

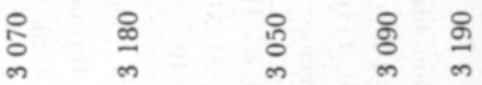

\& $\stackrel{9}{9}$ \%

స్ సి

\& \&

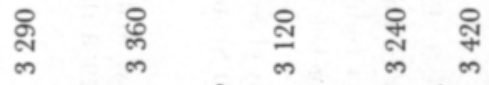

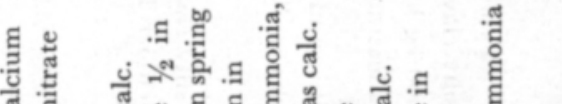

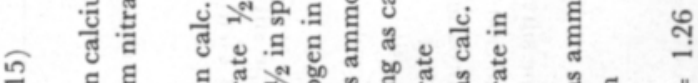

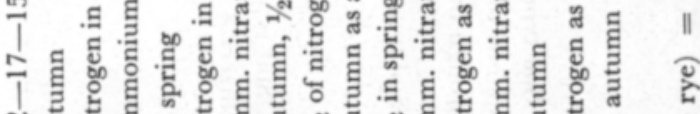

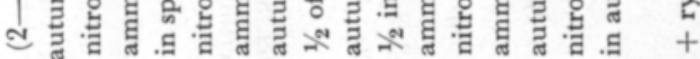

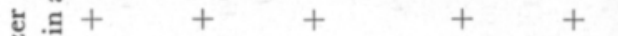

절

인

音 \&

\section{Results}

The results of the experiments are given in Tables $2-6$. Used in autumn on winter wheat and rye ammonia proved (Table 2) to have a fertilizing effectiveness as good as 


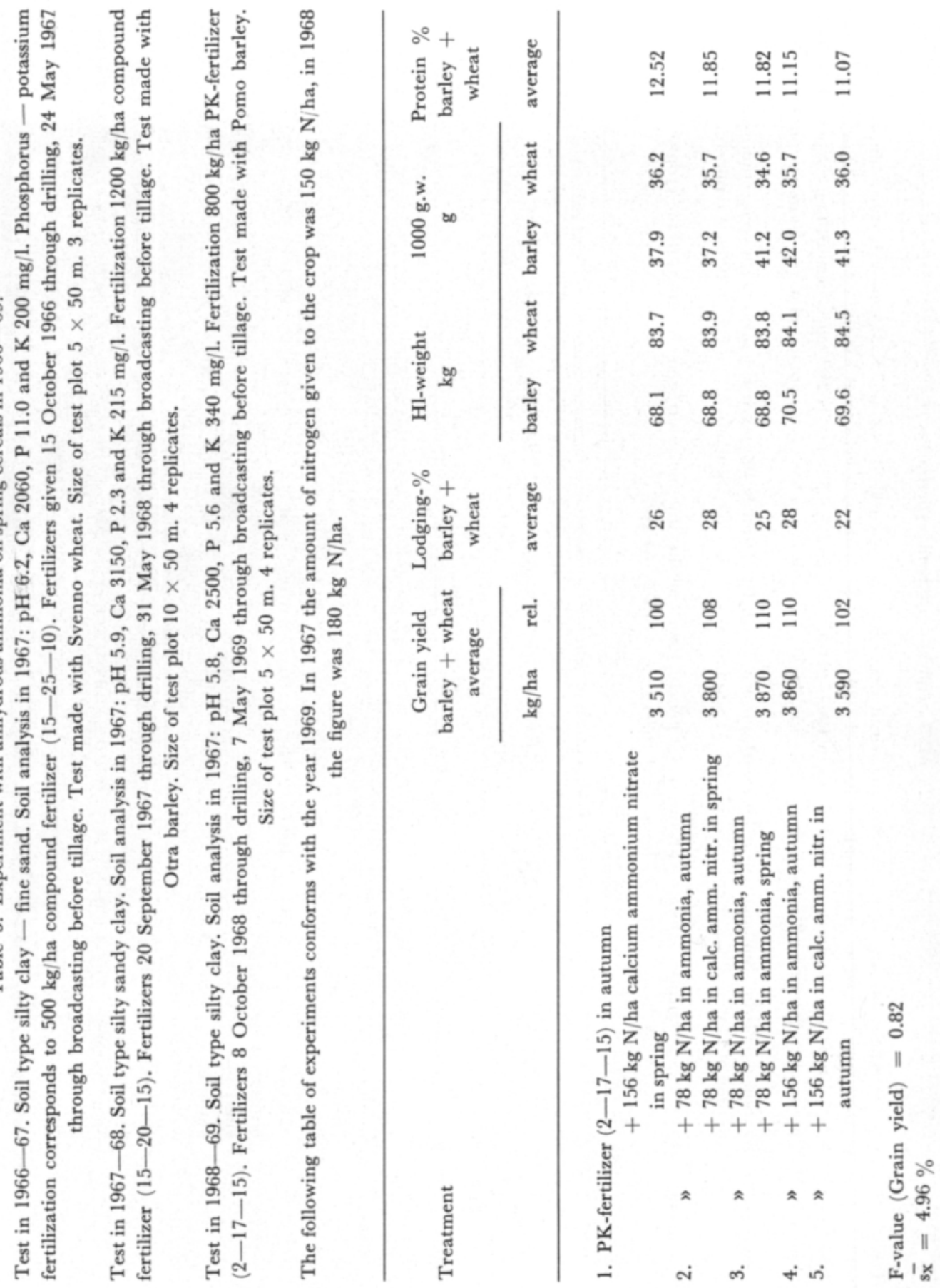

that of calcium ammonium nitrate or even better, similarly on spring wheat and barley (Table 3). No differences can be seen in the hl-weights, in the 1000 grain weights or in the crude protein. When comparing ammonia, calcium ammonium nitrate and urea 


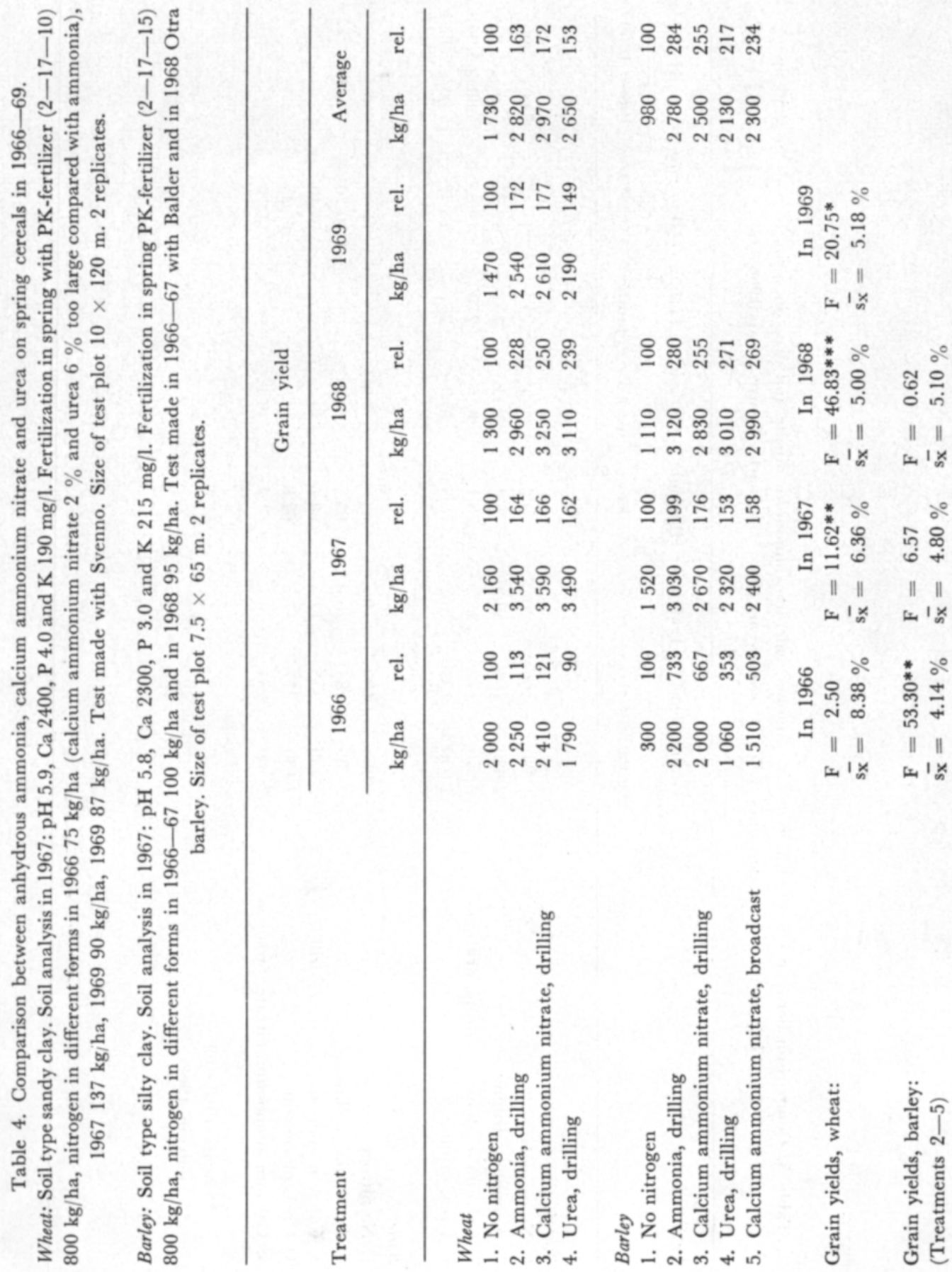

(Tables 4 and 5) on wheat, ammonia gave a $5 \%$ and urea an $11 \%$ lower yield than calcium ammonium nitrate. On barley ammonia gave an $11 \%$ higher yield than calcium ammonium nitrate and urea a $15 \%$ weaker yield than calcium ammonium nitrate. Especially in 1966 urea gave a poor yield. As to the components, such as falling number 


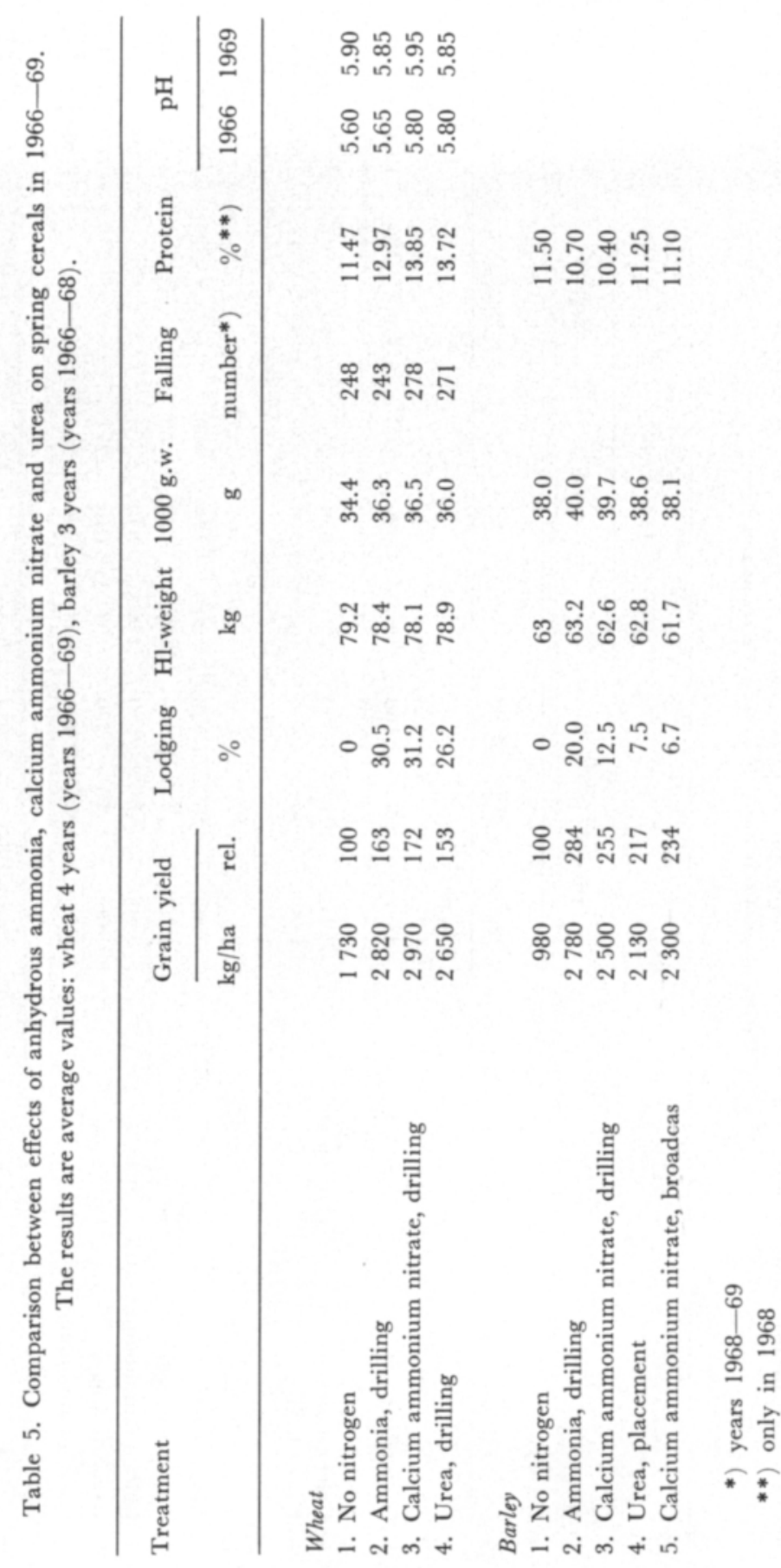

and protein content, having an effect on the crop quality there are no differences between different fertilizers, nor are there any differences in the changes of the soil $\mathrm{pH}$.

The crop yields obtained with pea-oats shown in Table 6 are the same in the cases of ammonia and compound fertilizer and additional nitrogen given in spring. 
Table 6. Experiment with anhydrous ammonia on pea-oats mixture. Soil type clayey sand and silt. Soil analysis in 1967: pH 6.4, Ca 1600 , P 24.0 and $\mathrm{K} 470 \mathrm{mg} / \mathrm{l}$. In spring $500 \mathrm{~kg}$ compound fertilizer $(15-25-10)$ by drilling $+200 \mathrm{~kg} / \mathrm{ha}$ calcium nitrate by broadcasting on shoots. Test made with peaoats mixture (Pendek + Kalle). Size of test plot $5 \times 30 \mathrm{~m} .4$ replicates.

\begin{tabular}{lrrr}
\hline Treatment & Grain & yield & Lodging \\
\hline & $\mathrm{kg} / \mathrm{ha}$ & $\mathrm{rel}$. & $\%$ \\
& 3059 & 100 & 95 \\
1. $75 \mathrm{~kg} \mathrm{~N} / \mathrm{ha}$ as $\mathrm{NH}_{3}$ previous autumn & 3037 & 99 & 95
\end{tabular}

Test plot was so heavily fertilized in spring ( $500 \mathrm{~kg} / \mathrm{ha}$ compound fertilizer $(15-20-15)+200 \mathrm{~kg} / \mathrm{ha}$ calcium nitrate) that ammonia used in autumn did not have an increasing effect on the crop.

F-value $=0.05$

$\mathrm{S}_{\mathbf{x}}^{\overline{-}}=9.70 \%$

\title{
REFERENCES
}

Anon. 1968. Review of Liquid Nitrogen Fertilizer Developments and Usage. Nitrogen No. 44, 15-20, 36. London.

Anon. 1969. Fra forsogene med flygende ammoniak 1961-68. Gədningen No. 2: 27-32. København. Buchner, A. 1966. Die Aussichten der Anwendung von wasserfreien Ammoniak im Bundesgebiet. Landwirtsch. Forsch. 19: 185-195.

van Burg, P. F. J. 1966. Versuchsergebnisse der Düngung von Acker und Grünland mit flüssigem Ammoniak. Ibrd. 19: 163-184.

- - von BrAKeL, G. D. \& Schepers, J. H. 1967a. The agricultural value of anhydrous ammonia on grassland: experiments $1963-65$. Netherlands nitrogen technical bulletin No. 2: $1-31$.

$-\gg$ 1967b. The agricultural value of anhydrous ammonia on arable land: experiments 1963 - 66 . Ibrd. No. 3: 1-39.

- - 1969. The Agronomic Value of Anhydrous Ammonia in Western Europe. Outlook Agr. 6: 55 - 9.

CоOKE, G. W. 1968. Rothamsted experimental station. Report for 1968, part 1: 38-62.

JANsson, L. S. 1966. Aktuella synpunkter på flytande ammoniak som kvävegödselmedel. Växt-näringsnytt $4: 1-8$.

SALONEN, M. 1967. Ammoniakki typpilannoitteena. Koetoim. ja Käyt. 24: 5, 7.

\section{SELOSTUS}

\section{NESTEMÄISEN AMMONIAKIN LANNOITUSKOKEIDEN TULOKSIA}

\author{
Yrjö Pessi, Jorma Syvälahti, Auvo Leskelä ja Mikko Ylänen
}

Rikkihappo Oy, Helsinki

Kevätviljojen lannoituksessa sekä syysviljojen kylvömuokkauksen yhteydessä annettavassa lannoituksessa on nestemäinen ammoniakki osoittautunut Rikkihappo Oy:n Kotkaniemen koetilalla vaikutukseltaan kalkkiammonsalpietarin veroiseksi. Viitenä vuotena on järjestetty sijoituslannoitusta käyttäen 16 koetta maalajin ollessa useimmissa kokeissa hiesusavea. Eroavuutta ei ole esiintynyt jyväsadon määrässä, 1000 -jyvän ja hehtolitran painossa eikä jyväsadon valkuaispitoisuudessa. Urea osoittautui vaikutukseltaan molempia lannoitteita huonommaksi. 